\title{
Physicochemical Properties of Low-Fat Yoghurt with Whey Protein Isolates as Fat Alternative
}

\section{Ayşe Demet KARAMAN ${ }^{1}$

\author{
${ }^{1}$ Aydın Adnan Menderes University, Agriculture Faculty, Dairy Technology Department, Aydın, Turkey
}

\begin{abstract}
In this research, the effect of whey protein isolates (WPI) as a fat alternative on the physicochemical properties of low-fat (1-2 \%) yoghurt samples during 14 days of storage was determinated. The samples were analyzed for their chemical composition, syneresis, tyrosine, firmness, color, and free fatty acids. Yoghurt having $2 \%$ of WPI showed significantly higher amount of tyrosine but lower syneresis; as total solids, protein, and fat were higher than the low-fat yoghurts $(1 \%$ WPI and low-fat control, $\mathrm{p}<0.05)$. However, WPI addition decreased the white and green tones but increased the yellow; thus, the addition of WPI didn't affect the opacity and brightness of low-fat yoghurt. The addition of WPI also gave rise to the amounts butyric, capric, and oleic acids during storage $(p<0.05)$. Herein we propose $2 \%$ WPI as a fat alternative to improve the physicochemical properties of low-fat for a storage duration of 14 days.
\end{abstract}

Keywords: low-fat yoghurt; whey protein isolates; physicochemical properties; free fatty acids; fat replacer

Yağ Alternatifi Olarak Serum Protein İzolatları İlaveli Düşük Yağlı Yoğurtların Fiziko Kimyasal Özellikleri

Öz: Bu çalışmada, 14 günlük depolama süresince, az yağı (\% 1-2) yoğurt numunelerinin fizikokimyasal özellikleri üzerine yağ alternatifi olan serum protein izolatının (WPI) kullanımının etkisi belirlenmiştir. Yoğurt örneklerinin kimyasal bileşimleri, sinerez, tirozin, sertlik, renk ve serbest yağ asitleri tespit edildi. \%2 WPI katkılı yoğurt örneklerinin, önemli ölçüde daha yüksek miktarda tirozin, ancak daha düşük sinerez göstermiştir; kurumadde bileşenlerinden protein ve yağ, az yağlı yoğurtlardan daha yüksek değerde olduğu saptanmıştır (\% 1 WPI katkılı ve yağsız kontrol grubu, $p<0.05)$. Bununla birlikte, WPI ilaveli yoğurtlarda beyaz ve yeşil renk tonları azalmış, sarı renk tonunu ise artırmıştır. Bu nedenle, WPI'nın eklenmesi, az yağlı yoğurtun opaklığını ve parlaklığını etkilememiştir. Ayrıca WPI ilavesi depolama sırasında butirik, kaprik ve oleik asit miktarlarında artışa neden olmuştur ( $p$ <0.05). Bu çalışmada, \% 2 WPI ilavesi 14 günlük depolama süresince düşük yağlı yoğurtların fiziko kimyasal özelliklerini iyileştirilmesinde bir yağ alternatifi olarak önerilmektedir.

Anahtar Kelimeler: az yağlı yoğurt; serum protein izolatları; fiziko kimyasal özellikleri; serbest yağ asitleri; yağ ikame

\section{INTRODUCTION}

The market for functional and convenience food is widening day-by-day as the public is getting aware of healthy diets (Lasik et al., 2016). Yoghurt has gained considerable economic importance as it is healthy and nutritious (Guggisberg et al., 2009). It is a type of miscellaneous, lactic acid-fermented milk product which suits all palates and meal occasions. In Turkey, it is frequently consumed either as a sole meal or as supplement. Turkish yoghurt production has been increased up to $4.5 \%$ from 2015 to 2016 i.e. 1173 million tons that makes a $25.2 \%$ market share of the dairy products. The average yoghurt consumption/person in Turkey is about $30 \mathrm{~kg} /$ year that is gradually increasing (Anonymous, 2016; Isleten and Karagul-Yuceer, 2006).

Fat plays an important role in the structural integrity and mouth feeling of yoghurt as it interacts with casein micelles. Less amount of fat in yoghurt leads to increased syneresis, poor texture, weak body, undesirable taste, and lower total solid content. Using whey proteins as a fat alternative in yoghurts could be a good practice due to their good nutritional and functional properties. Recently, the use of heat-treated whey protein concentrate (HPWC) as a fat alternative in non-fat goat milk yoghurt has suggested it as a possible fat alternative to improve the consistency of non-fat yoghurt. However, while the main constituent i.e. $\beta$-lactoglobulin is the same in WPI and WPC, WPI has a higher-purity whey protein then WPC. Also, WPI is high in calcium, minerals, and branched-chain amino acids such as valine, leucine, and isoleucine (Torres et al., 2018; Zhang et al., 2015).

These additional properties may increase the textural quality of yoghurt i.e. firmness, creaminess, viscosity, along with its health benefits and functional properties (Torres et al., 2018; Zhang et al., 2015). However, very limited work has been done on WPI usage as a fat alternative in yoghurt production. According to Torres et al. (2018), the addition of whey protein microparticles (MPWP) improved texture and rheological properties. But using MPWPs with a nonmicroparticulated source as WPI resulted in low-viscosity yoghurt. Zhang et al. (2015) suggested that WPC could be used as a fat replacer for goat milk yoghurt production to improve the texture and water holding capacity of yoghurt. More work is needed to explore WPI usage in reduced and whole-fat yoghurt production during storage.

Since free fatty acids (FFA) variation gives rise to changes in the organoleptic and nutritional properties of dairy products, they are important to be evaluated in yoghurt. Lipolysis occurs during storage where the FFAs are liberated

Sorumlu Yazar: demet.karaman@adu.edu.tr

Geliş Tarihi: 15 Temmuz 2019

Kabul Tarihi: 17 Aralık 2019 
and short chain fatty acids (SCFA) provides the sensory quality to the dairy products. Acetic, butyric, and oleic acids show antibiotic and anticancer properties that are important nutritional aspects of fatty acids (Reguła 2007). FFAs in yoghurt are influenced by the type of starter culture, quality of raw milk, and technological treatments such as incubation, cooling, and storage (Güler and GürsoyBalci 2011). Furthermore, milk protein usage in yoghurt as a fat replacer could be an effective FFA variation during storage. To the best of our knowledge, there is no report on this subject. Although, a number of authors have studied the free fatty acids in yoghurt (Güler 2007; Güler and Gürsoy-Balci 2011; Sumarmono et al., 2015) or the structural and sensory properties of yoghurt with WPI (Guggisberg., 2009; Guggisberg et al., 2007; Ibrahim et al., 2017; Matumoto-Pintro et al., 2011; Onsekizoglu Bagci and Gunasekaran 2016; Patocka et al., 2006; Shi et al.,2017; Walsh-O'grady et al., 2001; Wang et al., 2015; Zhang et al., 2015), scientific literature characterizing FFAs in WPI-added yoghurt is rare.

This study was aimed to: i) determine the variations that may develop in low-fat yoghurt's physiochemical properties by WPI addition during storage, ii) understand whether or not the FFA profiles of yoghurt were related to WPI addition, and iii) to investigate a novel approach to developing yoghurt using WPI as a fat replacer.

\section{MATERIALS AND METHODS}

\section{Materials}

Raw cow's milk for analysis was bulk collected from Omur Sut Mam. Ldt. Sti (Aydın, Turkey). Whey protein isolate (WPI) was obtained from Danisco Food International (Turker Teknik Company, istanbul, Turkey), with an approximate composition of $96 \%$ protein and $2 \%$ total fat, as stated by the manufacturer. A freeze-dried direct vat set thermophilic yoghurt culture (Yoflex: Express 1.0), composed of a mixture of Lactobacillus delbrueckii subsp. bulgaricus and Streptococcus thermophilus, was kindly provided by Maysa Starter Culture Company (Istanbul, Turkey).

\section{Methods}

\section{Yoghurt production}

Fatty raw milk was preheated to $55^{\circ} \mathrm{C}$ and standardized at $3 \%$ (fatty) and $0.5 \%$ (reduced fat) fat levels. After being heated to $95^{\circ} \mathrm{C}$ for $10 \mathrm{~min}$, the milk was cooled to $45^{\circ} \mathrm{C}$. At this stage, WPI was added at different levels (1 and $2 \%$ $\mathrm{w} / \mathrm{w}$ ) into the reduced-fat milk samples. Thus, four yoghurt samples were prepared as follows: $3 \%$ fat (Control, fatty yoghurt, FY), $0.5 \%$ fat (low-fat yoghurt, LY), $0.5 \%$ fat $+1 \%$ WPI (low-fat yoghurt with 1\% WPI, LY1), and $0.5 \%$ fat $+2 \%$ WPI (low-fat yoghurt with $2 \%$ WPI, LY2). After mixing in a blender, commercial yoghurt culture was added at a 224 concentration of $3 \%$ (after pre-activation). The inoculated milk samples were poured into $250 \mathrm{~g}$ plastic cups with lids and incubated at $43-45^{\circ} \mathrm{C}$. Incubation was ended when the experimental yoghurt samples reached $\mathrm{pH}$ 4.6-4.7. The fermentation times of all 4 types of set yoghurt were approximately $4 \mathrm{~h}$. Following incubation, yoghurt samples were cooled and stored at $3-5{ }^{\circ} \mathrm{C}$ for 14 days (Figure 1 ). Sample production and all the analyses were performed in triplicate.

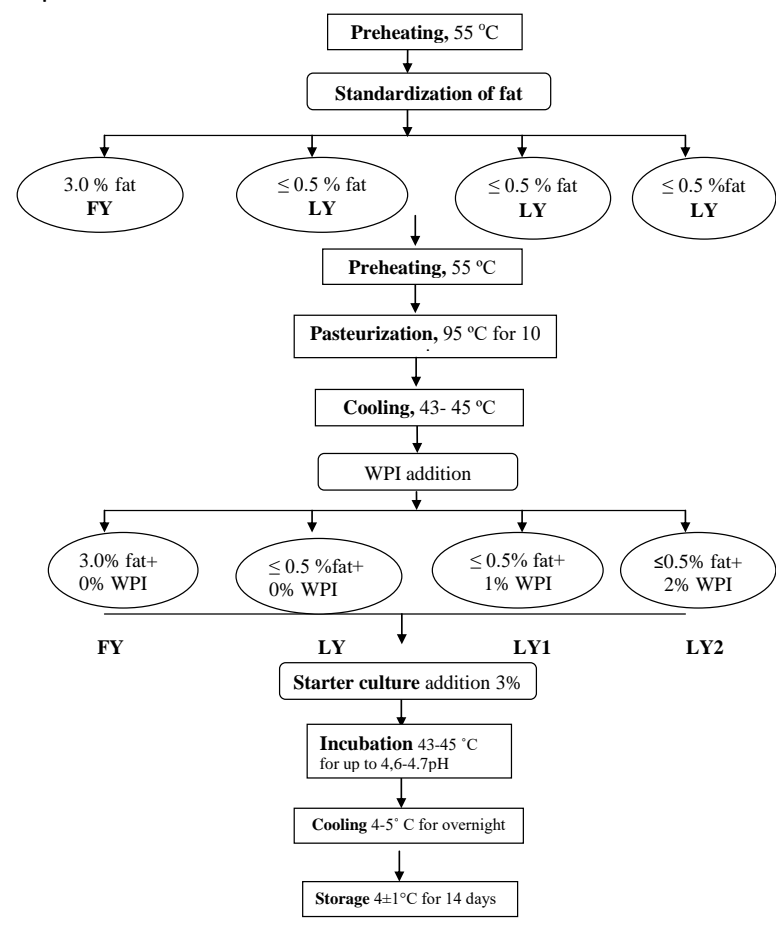

Figure 1. Flowchart illustrating the production of yogurts.

FY: Fatty yogurt (\% 3 fat+\% 0 WPI); LY: Low fat yogurt ( $\leq \%$ $0.5 \mathrm{fat}+\% 0 \mathrm{WPI}$ ); LY1: $1 \% \mathrm{WPI}$ added yogurt ( $\leq \% 0.5 \mathrm{fat}+\%$ $1 \mathrm{WPI}$ ); LY2: $2 \% \mathrm{WPI}$ added yogurt ( $\leq \% 0.5$ fat $+\% 2 \mathrm{WPI})$.

\section{Some physicochemical properties of milk samples}

The basic chemical composition of raw milk (total solid and fat) was determined by gravimetric and Gerber methods (Anonymous 1994). Protein contents were analyzed according to the Kjeldahl method (AOAC 2010). Milk pH was measured using a $\mathrm{pH}$ meter (Adwa, Romania) with a combined glass electrode.

\section{Yoghurts analyses}

The total solid and fat contents of the yoghurt samples were determined by the standard Turkish methods (Anonymous 1989). The titratable acidity (TA, \%) and ash content were detected according to AOAC standards (AOAC 2000, 2010). Total nitrogen was determined by the Kjeldahl method and protein content was calculated using a 
conversion factor of 6.38. Tyrosine value and syneresis were measured according to Hull (1947) and Guggisberg et.al (2011) respectively. The firmness (F35 mm) of yoghurt samples was measured using a Universal Testing Machine equipped with a $500 \mathrm{~N}$ force sensor (Zwick/Roel Z.05 TH, Zwick, Germany) and a cylinder ( $h=12.5 \mathrm{~cm}, \emptyset=6 \mathrm{~cm})$ (Guggisberg et al., 2011). A Hunter Lab Color Flex EZ spectrophotometer (S/N CFEZ 1209 Model, Hunter Associates Laboratory, Inc., Reston, VA, USA) was used to measure the yoghurt's whiteness (L), greenness (a) and yellowness (b). All $L, a$, and $b$ values were taken per single sample in triplicate at different sites, and the average was calculated. Free fatty acids were analyzed using an Agilent GC (model GC 6890N) equipped with a capillary column (300 x 250 $\mu \mathrm{m} \times 0.25 \mu \mathrm{m}$, Agilent 19091F-433 HP-FFAP, CA, USA). The extraction was obtained according to reported method (Yıldız-Akgül 2018). The gas chromatography (GC) injection volume was $2 \mathrm{~mL}$ while the temperature of the GC oven was increased from 120 to $230 \stackrel{\circ}{ } \mathrm{C}$ at a rate of 10 oc/min. The split was set at 1:10. Fatty acid standards supplied as samples (Sigma-Aldrich, Germany) were prepared at 50, 100, 150, 200, and 250 ppm and injected for free fatty acid identification.

\section{Statistical analysis}

The data were analyzed using the SPSS (Version 18.0, SPSS Inc., USA) commercial statistical package. A critical level of significance at $p=0.05$ was used throughout the study. Analysis of variance was performed on each attribute and data were analyzed for treatment effects, storage effects, and treatment by 14 days of storage interactions. Any significant treatment, time, or interaction effect was described. Pearson's correlation coefficient test was used for multiple comparisons.

\section{RESULTS AND DISCUSSION}

\section{Physicochemical characteristics of milk}

The physicochemical composition of raw cow's milk was found as follows: fat $(3.87 \pm 0.64 \%)$, total solids (12.42 \pm $0.77 \%)$, protein (3.28 $\pm 0.03 \%)$, ash (0.68 $\pm 0.02 \%), \mathrm{pH}$ $(6.62 \pm 0.09)$, and density $(1.030 \pm 0.01 \mathrm{~g} / \mathrm{mL})$. The gross composition of the raw milk was in accordance with the Turkish Codex's Standard for Raw Milk (Anonymous 1994). Physicochemical characteristics of yoghurt during storage
Chemical characterization of the yoghurt samples with different levels of WPI ( $1 \%$ and $2 \%$ ) and at various fat ratios $(3.0 \%, 0.6 \%$, and $0.7 \%)$ are presented in Table 1 . WPI addition only caused an insignificant difference $(p>0.05)$ in ash content, which varied from $0.69-0.72 \%$. However, the total solids, fat, and protein contents were significantly different $(p<0.05)$. As expected, the yoghurt sample manufactured with 2\% WPI (LY2) presented significantly higher total solids and protein values (11.74\% and $5.39 \%$ ) compared to the other samples $(p<0.05)$, due to WPI addition at the $2 \%$ level. Surprisingly, the fat levels of the low-fat yoghurts (LY1 and LY2) were clearly increased by WPI addition level $(p<0.05)$. This result was in good agreement with (Guggisberg et al., 2007), who added WPI after heat treatment to manufacture low-fat yoghurt. According to the Turkish Codex's Standard for Fermented Milks (Anonymous 1989), yoghurt FY is classified as fatty yoghurt $(3.8 \%<)$ and the other samples are classified as low-fat yoghurt.

The physicochemical properties of yoghurts such as $\mathrm{pH}$, titratable acidity, and tyrosine during the 14-day storage are summarized and compared in Table 2. Generally, the physicochemical properties of all the samples were significantly ( $p<0.05$ ) influenced by the addition of WPI and storage time. As seen in Table 2, while regular increasing or decreasing trends were observed for $\mathrm{pH}$, titratable acidity, and tyrosine, the fluctuations unchanged over time.

The mean values of $\mathrm{pH}$ and titratable acidity were changed from 4.21 to 4.32 and 0.80 to $0.97 \%$, respectively (Table 2). First and $14^{\text {th }}$ day of storage showed that the $\mathrm{pH}$ and titratable acidity \% levels in WPI-containing yoghurts (LY1 and LY2) were higher than the other control samples (FY and $L Y)$. The $\mathrm{pH}$ and titratable acidity significantly $(\mathrm{p}<0.05)$ influenced by the addition of WPI. WPI-added yoghurt reflected high titratable acidity probably due to their high total solids and protein (Table 1) as reported earlier (Guggisberg et al., 2007; Güler and Park, 2011). There were remarkable increases in titratable acidity levels and decreases in $\mathrm{pH}$ levels until day 14, reaching maximum levels for all samples. Storage time caused a significant increase in the acidity of the yoghurt samples (decrease in $\mathrm{pH}$ values, $\mathrm{p}<0.05)$. A decrease in $\mathrm{pH}$ is expected during

Table 1. Chemical compositions of yoghurt samples $(n=3)$

\begin{tabular}{lllll}
\hline Samples* & Total solids (\%) & Fat (\%) & Protein (\%) & Ash (\%) \\
\hline FY & $11.09 \pm 0.17^{\mathrm{c}}$ & $3.00 \pm 0.00^{\mathrm{c}}$ & $2.86 \pm 0.15^{\mathrm{a}}$ & $0.69 \pm 0.00^{\mathrm{a}}$ \\
LY & $9.42 \pm 0.07^{\mathrm{a}}$ & $0.60 \pm 0.00^{\mathrm{a}}$ & $3.33 \pm 0.33^{\mathrm{b}}$ & $0.70 \pm 0.00^{\mathrm{a}}$ \\
LY1 & $10.36 \pm 0.07^{\mathrm{b}}$ & $0.60 \pm 0.00^{\mathrm{a}}$ & $4.25 \pm 0.19^{\mathrm{c}}$ & $0.71 \pm 0.00^{\mathrm{a}}$ \\
LY2 & $11.74 \pm 0.13^{\mathrm{d}}$ & $0.70 \pm 0.00^{\mathrm{b}}$ & $5.39 \pm 0.30^{\mathrm{d}}$ & $0.72 \pm 0.00^{\mathrm{a}}$ \\
\hline
\end{tabular}

*FY: Fatty yogurt (\% 3 fat+\% 0 WPI); LY: Low fat yogurt ( $\leq \% 0.5$ fat+\% 0 WPI); LY1: $1 \%$ WPI added yogurt ( $\leq \% 0.5$ fat+\% 1 WPI); LY2: $2 \%$ WPI added yogurt ( $\leq \% 0.5$ fat $+\% 2$ WPI).

Superscript lowercase letters means significant difference $(p<0.05)$. 
Table 2. Physicochemical compositions of yoghurt samples during storage for 14 days $(n=3)$

\begin{tabular}{|c|c|c|c|c|c|}
\hline Parameter* & Samples & Day 1 & Day 7 & Day 14 & Mean /Average \\
\hline \multirow{4}{*}{$\mathrm{pH}$} & FY & $4.25 \pm 0.02 c A$ & $4.20 \pm 0.03 \mathrm{bA}$ & $4.18 \pm 0.03 a A$ & $4.21 \pm 0.04 \mathrm{~A}$ \\
\hline & LY & $4.26 \pm 0.01 c B$ & $4.23 \pm 0.02 b B$ & $4.21 \pm 0.02 \mathrm{aB}$ & $4.23 \pm 0.03 B$ \\
\hline & LY1 & $4.34 \pm 0.04 c C$ & $4.29 \pm 0.02 b C$ & $4.28 \pm 0.02 \mathrm{aC}$ & $4.30 \pm 0.04 C$ \\
\hline & LY2 & $4.42 \pm 0.03 c D$ & $4.28 \pm 0.02 b D$ & $4.26 \pm 0.02 \mathrm{aD}$ & $4.32 \pm 0.08 \mathrm{D}$ \\
\hline \multirow{4}{*}{$\begin{array}{l}\text { Titratable } \\
\text { acidity, LA, } \\
\%\end{array}$} & FY & $0.76 \pm 0.02 a A$ & $0.79 \pm 0.02 b A$ & $0.85 \pm 0.00 \mathrm{cA}$ & $0.80 \pm 0.04 \mathrm{~A}$ \\
\hline & LY & $0.79 \pm 0.03 a \mathrm{~B}$ & $0.79 \pm 0.02 b B$ & $0.85 \pm 0.01 c B$ & $0.81 \pm 0.03 B$ \\
\hline & LY1 & $0.85 \pm 0.01 \mathrm{aC}$ & $0.85 \pm 0.01 b c$ & $0.93 \pm 0.04 c C$ & $0.87 \pm 0.05 C$ \\
\hline & LY2 & $0.92 \pm 0.03 a \mathrm{a}$ & $0.96 \pm 0.02 b D$ & $1.03 \pm 0.01 c D$ & $0.97 \pm 0.05 D$ \\
\hline \multirow{4}{*}{$\begin{array}{l}\text { Tyrosine, } \\
\mathrm{mg} / 5 \mathrm{~g}\end{array}$} & FY & $0.32 \pm 0.01 \mathrm{aA}$ & $0.36 \pm 0.01 b A$ & $0.37 \pm 0.01 c A$ & $0.35 \pm 0.02 \mathrm{~A}$ \\
\hline & LY & $0.35 \pm 0.01 \mathrm{aB}$ & $0.37 \pm 0.01 b B$ & $0.37 \pm 0.01 c B$ & $0.36 \pm 0.01 B$ \\
\hline & LY1 & $0.44 \pm 0.01 \mathrm{aC}$ & $0.45 \pm 0.01 b c$ & $0.45 \pm 0.01 c C$ & $0.45 \pm 0.01 \mathrm{C}$ \\
\hline & LY2 & $0.44 \pm 0.02 \mathrm{aC}$ & $0.44 \pm 0.02 b c$ & $0.47 \pm 0.02 c C$ & $0.45 \pm 0.03 C$ \\
\hline
\end{tabular}

* FY: Fatty yoghurt (\% 3 fat+\% 0 WPI); LY: Low fat yoghurt ( $\leq \% 0.5$ fat+\% 0 WPI); LY1: $1 \%$ WPI added yoghurt $(\leq \% 0.5$ fat+\% $1 \mathrm{WPI}$ ); LY2: $2 \% \mathrm{WPI}$ added yoghurt ( $\leq \% 0.5$ fat $+\% 2 \mathrm{WPI})$.

${ }^{a-c}$ The same column with different superscripts among yoghurt samples significantly differ $(P<0.05)$

A-D The same row with different superscripts among yoghurt samples significantly differ $(p<0.05)$

storage as a result of the accumulation of lactic acid produced by the bacteria similar to the related fermented foods (Damin et al., 2009).

Tyrosine detection tracks released $\alpha$-amino groups due to proteolysis of the milk proteins, that indicates the proteolytic activity of the starter culture. Exceeding from $0.5 \mathrm{mg} / \mathrm{mL}$ can cause certain flavor defects, such as bitterness, depending on the storage time, culture type, and protein structure in the yoghurt (Kesenkaş et al., 2011). In this study, the tyrosine levels of the yoghurt samples during the 14-day storage period were observed in the range of $0.32-0.47 \mathrm{~mL} / 5 \mathrm{~g}$. The tyrosine value of the yoghurt samples did not reach a certain threshold value; thus the flavor of the yoghurt maintains at the end of the storage. Similarly, storage time and WPI addition significantly affected the tyrosine values in this study ( $p<0.05$ ). Tyrosine levels in the WPI-containing yoghurts (LY1 and LY2) were significantly higher $(p<0.05)$ as compared to the controls (FY and LY) at the beginning and end of the storage period (Table 2). This can be related to the higher total solids content of the samples LY1 and LY2 vs. the controls (Table 1). The amount of tyrosine in all yoghurt samples was higher at the end of the storage than on day 1 with significant fluctuations over time $(p<0.05)$. Similar results were obtained by Şenel et al. (2011).

Texture is one of the main factors affecting yoghurt quality. Poor texture and syneresis reduce its appeal to consumers (Lasik et al., 2016). Figure 2 shows the changes in syneresis over 14 days of storage. The syneresis was influenced by WPI addition and fat content $(p<0.05)$. No effect of storage was detected $(p>0.05)$. The $2 \%$ WPI added yoghurt (sample LY2) had the lowest level of syneresis at the beginning and at the end of the storage. High amount of total solids ( $11.74 \%$, Table 1 ) in LY2 partially responsible for the low syneresis observed during the whole storage

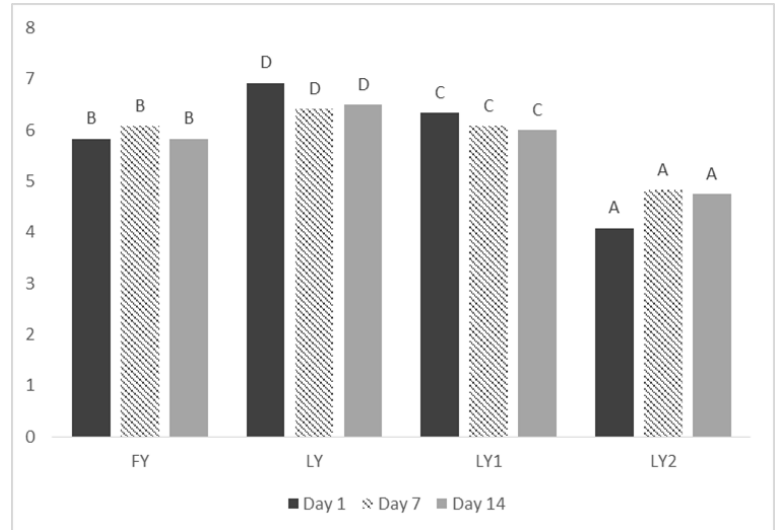

Figure 2. Syneresis of yoghurt samples during 14 days of storage $(n=3)(\mathrm{mL} / 10 \mathrm{~g})$.

A-D Bars within the same day not sharing a common uppercase letter are different $(p<0.05)$; FY: Fatty yoghurt $(\%$ 3 fat+\% 0 WPI); LY: Low fat yoghurt ( $\leq \% 0.5$ fat+\% 0 WPI); LY1: $1 \%$ WPI added yoghurt ( $\leq \% 0.5$ fat+\% 1 WPI); LY2: $2 \%$ WPI added yoghurt ( $\leq \% 0.5$ fat $+\% 2 \mathrm{WPI})$.

period (4.08 and 4.75, Figure 2). On the other hand, sample LY (low-fat) consistently displayed higher syneresis (between 6.92 and 6.50) compared with the other yoghurts ( $p<0.05)$, which could be related to the low total solids (9.42\%), as well as the least fat content (0.6\%) (Table 1$)$. Such behavior can be explained by their higher solids and fat concentration; thus the possibility of building a more cohesive polymer network to reduce the syneresis. This observation is in agreement with the results of (Kaminarides et al., 2007) comparing the yoghurts containing 6.6 and $0.9 \%$ fat content. Since $\mathrm{pH}$ decreases during storage (Table 2), unexpectedly, there were abrupt ups and downs in syneresis; although these changes (throughout the storage) were statistically insignificant $(p>$ 
0.05). Increases (Onsekizoglu Bagci and Gunasekaran, 2016) and decreases (Isleten and Karagul-Yuceer, 2006; Matumoto-Pintro et al., 2011) in the syneresis of WPIadded yoghurts during storage have also been reported in previous studies.

The results of textural examinations of firmness are presented in Figure 3. The firmness of the control fatty yoghurt $(F Y)$ was significantly $(p<0.05)$ higher than the others at the beginning of the storage. This could be related to the firmness of yoghurts increasing as the fat content

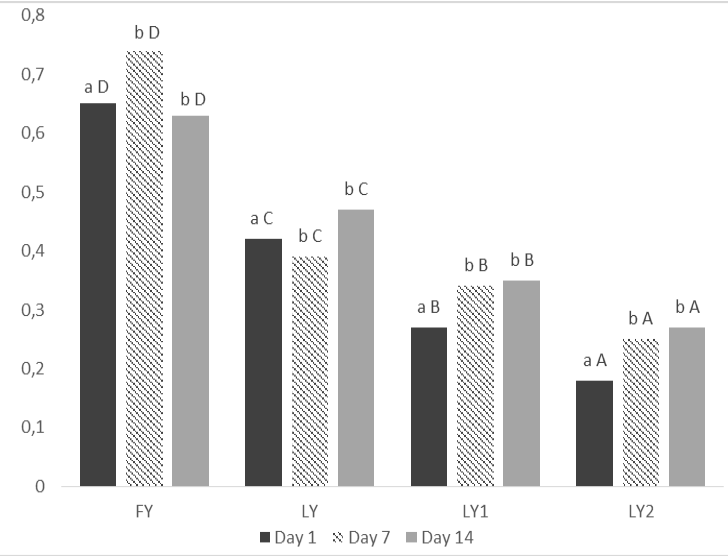

Figure 3. Firmness of yoghurt samples during 14 days of storage $(n=3)(N)$.

A-D Bars within the same day not sharing a common uppercase letter are different $(p<0.05) ;{ }^{a-c}$ Bars not sharing a common lowercase letter are different for storage period ( $p<0.05)$. FY: Fatty yoghurt (\% 3 fat+\% 0 WPI); LY: Low fat yoghurt ( $\leq \% 0.5$ fat+\% 0 WPI); LY1: $1 \%$ WPI added yoghurt ( $\leq \% 0.5$ fat+\% $1 \mathrm{WPI}) ;$ LY2: $2 \% \mathrm{WPI}$ added yoghurt $(\leq \% 0.5$ fat $+\% 2$ WPI). increased. The lower firmness of sample LY2 (2 \% WPI added), LY1 and LY can be an outcome of the lower syneresis (Figure 2) and higher total solids (Table 1) as observed previously (Kaminarides et al., 2007; Wang et al., 2015). Similarly, the firmness changed during storage $(p<$ 0.05). The firmness values of sample FY (fatty) control yoghurts decreased but increased for other samples at the end of the storage. Yoghurt color is another powerful quality descriptor and consumer acceptance quality attribute. The color values depend on the type of milk used in the yoghurt-making, the chemical composition of the yoghurt, and the yoghurt-making technique since the gel opacity is related to fat content, casein ratio, and the aggregation level of fat and casein (Güler and Park 2011). On the first day of storage, the color of the yoghurt samples was significantly influenced $(p<0.05)$ by WPI addition (Figure 4). The $\mathrm{L}$ (whiteness) values of WPI-containing yoghurt (LY1-LY2) were significantly lower $(p<0.05)$ than the low-fat and fatty control yoghurts (LY, FY). However, during storage, the $L$ value decreased for the low-fat and WPI-containing yoghurts (LY, LY1, LY2) but increased for the sample (fatty) control yoghurt (FY). The highest fat level of FY yoghurt may have increased the whiteness of the yoghurt.

All the yoghurt samples showed a negative value, indicating greenness. WPI addition contributed more to the green color compared to the low-fat control yoghurt (without WPI). However, alteration was observed after 7 days of storage. At day 1 of storage, WPI addition implied more yellowing (higher b value) than the control yoghurt. Further increases in the $b$ values were statistically insignificant for any of the yoghurt samples at the end of the storage $(p>$

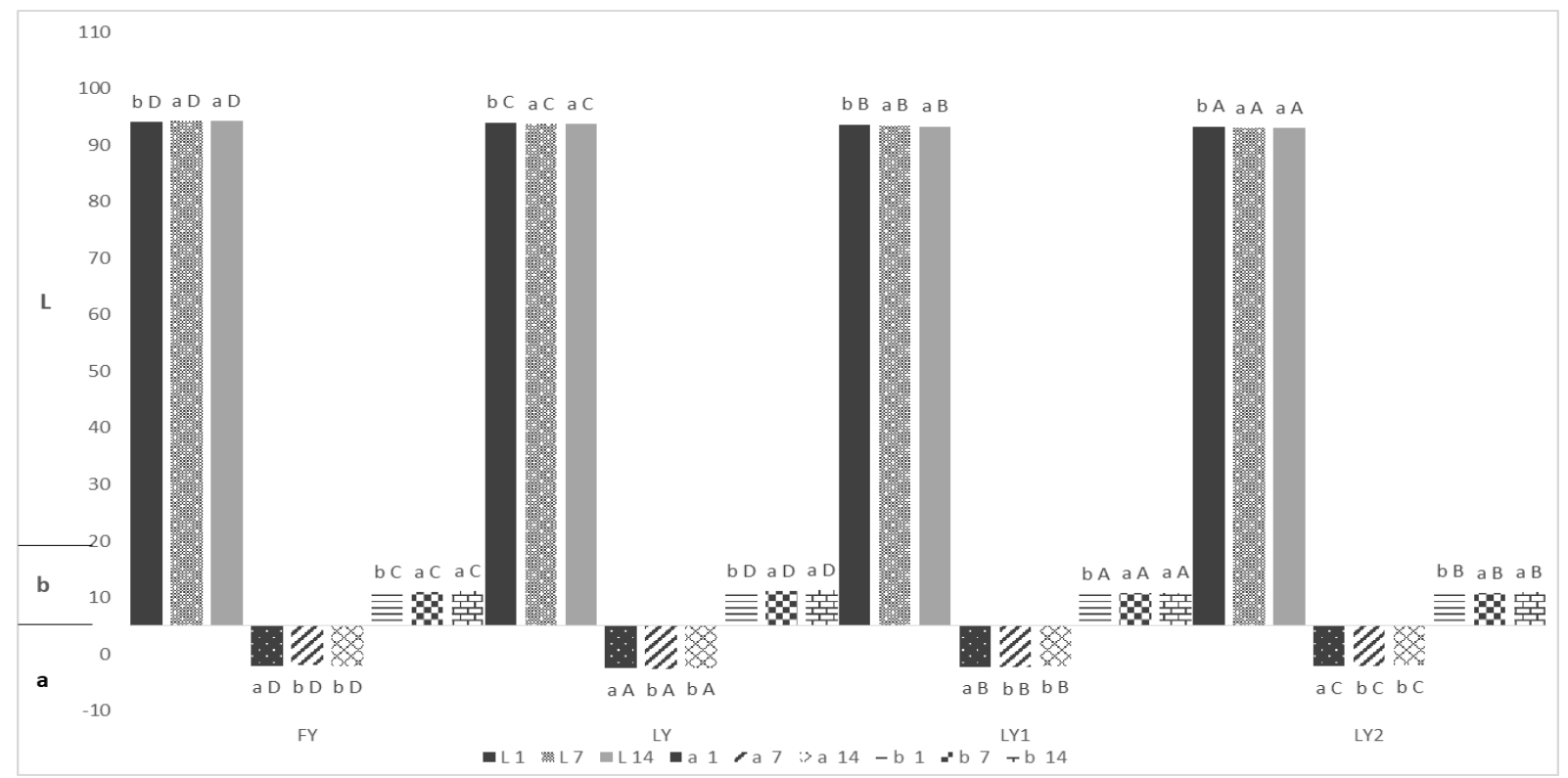

Figure 4. Color properties of yoghurt samples during 14 days of storage $(n=3)$

${ }^{A-D}$ Bars within the same day not sharing a common uppercase letter are different $(p<0.05)$; ${ }^{a-c}$ Bars not sharing a common lowercase letter are different for storage period $(p<0.05)$. FY: Fatty yoghurt (\% 3 fat+\% 0 WPI); LY: Low fat yoghurt ( $\leq \%$ 0.5 fat+\% 0 WPI); LY1: $1 \%$ WPI added yoghurt ( $\leq \% 0.5$ fat+\% 1 WPI); LY2: $2 \%$ WPI added yoghurt $(\leq \% 0.5$ fat $+\% 2$ WPI). 
0.05). So, WPI addition was characterized by significantly lower whiteness, lower greenness, and higher yellowness than the fatty control yoghurts (FY) possibly due to the presence of more fat globules and lower protein levels (Table 1) than other samples at day 1.

At the end of the storage, WPI-containing yoghurts (LY1, LY2) had higher greenness (a) but less yellowness (b) and whiteness (L) than sample LY (low fat); that means opacity and higher brightness wasn't observed with WPI addition (Figure 4). However, there were no statistically significant differences between the first and last day of storage on the yellowness (b) of all samples ( $p>0.05$ ). Yıldı-Akgül 2018 studied the color change of WPI- added Torba yoghurt during 14 days of storage. The author observed a decrease in whiteness (L) and greenness (a) but an increase in yellowness (b) during storage. Fermented beverages prepared from milk with an increased proportion of whey proteins to caseins were also observed to have a significantly higher value of yellowness (b) and greater lightness (Lasik et al., 2016).

\section{Free fatty acid profiles of yoghurts during storage}

The samples having free fatty acids from C4 to C18:1 are given in Table 3. The most abundant FFAs in the samples were palmitic (C16) and myristic (C14) acids with concentrations of 97.55-44.26 and 31.76-18.07 ppm, respectively. The short- (C4-C10, SCFA), medium- (C12-C14, MCFA), and long-chain (C16, C18, LCFA) FFAs represented 3.22-11.54, 0.94-31.54, and 4.12-97.55 ppm, respectively. Quantifying the levels of short-chain FFAs is important since their concentration can cause flavor changes and defects. However, despite the quantitative importance of medium and long-chain FFAs, they are not the main contributors of flavor to the dairy products (Güler and Park, 2011).

In the present study, the short-chain fatty acids i.e. butyric, caproic, caprylic, and capric acids were most abundant in the FY (fatty) control yoghurt at day 1 . The addition of WPI affected $(p<0.05)$ the SCFA levels. Yoghurts containing 1 and $2 \%$ WPI- (LY1, LY2) had lower levels than fatty and lowfat control yoghurts (without WPI). Similar trends were observed at day 7 and 14 . Caproic (C6) and caprylic (C8) levels in all yoghurt samples decreased during the storage $(p<0.05)$. However, the butyric (C4) and capric acid (C10) levels of only LY2 (2\% WPI added) were significantly increased from day 1 up to 14 . This could be related to not only the formation of volatile fatty acids, which are responsible for the formation of free fatty acids from lipolysis, but also to amino acid degradation (Beshkova et al., 1998; Güler and Park, 2011). Similar results were also obtained after 21-day storage of yoghurt by Güler and Gürsoy-Balcı (2011).

When it comes to the medium-chain free fatty acids, lauric (C12) and myristic (C14) acids presented similar behavior in all samples at the beginning of storage. MCFA levels in all samples were significantly affected by the WPI addition and storage time $(p<0.05)$. Regardless of WPI addition, the levels of lauric and any myristic acids (C12-C14) were significantly lower in the WPI-containing yoghurts (LY1, LY2) than in non-WPI yoghurts (FY, LY). Lauric acid increased steadily in all the yoghurts during storage. However, no regular trend of increasing and decreasing was observed in myristic acid (C14) levels during the storage of all samples. Similar results were obtained in a study related to strained yoghurt during storage (Şenel et al., 2011).

Regarding long-chain fatty acids (LCFAs), palmitic (C16), stearic (C18), and oleic acid (C18:1) levels were significantly affected by the WPI addition during the first and last day of storage ( $p<0.05$ ). Being fatty, the FY (without WPI) control yoghurt had more LCFAs than other yoghurts. Similar to MCFAs, the LY2 (2 \% WPI added) was lower than all samples in terms of LCFAs. The levels of LCFAs in all yoghurts were significantly $(p<0.05)$ affected by the storage period, with markedly lowered stearic acid (C18) levels while the palmitic (C16) and oleic acid (C18:1) levels were increased. In the literature, there are conflicting data concerning the lipolytic activity of yoghurt starters. Guler and Gürsoy-Balcı (2011) demonstrated the decrease in LCFAs in yoghurt, while Rao and Reddy (1984) found an increase in stearic and oleic acids. Oleic acids showed the same profile as palmitic acid in yoghurts and it was the second most abundant LCFA in the samples. The release of free fatty acids from triglycerides continues to occur during the process of lipolysis (Sumarmono et al., 2015).

Generally, it can be surmised that WPI addition affects the direction and intensity of changes in FFA levels during storage. The 2 and $1 \%$ WPI-added yoghurts (LY2 and LY1) had the least short-, medium-, and long-chain fatty acids. However, irregular changes were observed during the storage. Contrary to expectations, there were increases in SCFAs (butyric and capric acid), MCFAs (myristic acid), and LCFAs (palmitic and oleic acid) during storage in the $2 \%$ WPI-added sample (LY2). This could be related to the higher fat content in LY2 compared to LY and LY1 (Table 1). So, using WPI as a fat alternative in low-fat yoghurt affected FFA variation in storage.

\section{CONCLUSION}

The result obtained contributes to the physicochemical properties and free fatty acid composition of WPI-added low-fat yoghurts. Significant differences were found in the WPI-added yoghurts at the beginning and at the end of storage period $(p<0.05)$. A $2 \%$ WPI addition increased total solids, protein, and fat levels of low-fat yoghurt. Similarly, the titratable acidity and tyrosine levels were higher with lower syneresis and texture enhancements, comparatively. However, WPI addition decreased the whiteness ( $\mathrm{L}$ ) and greenness (a) with an increase in the yellowness (b). Using a WPI generally resulted in a decrease of short-, medium-, and long-chain fatty acids. However, during the storage time, the levels of butyric, capric, myristic, palmitic, and oleic acid increased in the $2 \%$ WPIadded yoghurts. These results indicate that WPI could be used as a fat alternative in low-fat yoghurt. However, more work is needed to gain detailed information about the microstructures, sensory characteristics, and microbial characteristics of low-fat yoghurt with $2 \%$ WPI. 
Table 3. Fatty acid profiles of yoghurt samples during 14 days of storage, $(n=3)(p p m)$.

\begin{tabular}{|c|c|c|c|c|c|}
\hline Parameter* & Samples & Day 1 & Day 7 & Day 14 & $\begin{array}{l}\text { Mean } \\
\text { /Average }\end{array}$ \\
\hline \multirow{4}{*}{ Butyric, C4 } & $\mathrm{FY}$ & $5.17 \pm 0.82 \mathrm{aB}$ & $5.24 \pm 0.60 \mathrm{aB}$ & $7.17 \pm 0.51 b B$ & $5.86 \pm 1.14 \mathrm{~B}$ \\
\hline & LY & $3.67 \pm 0.20 \mathrm{aA}$ & $3.22 \pm 0.17 a A$ & $3.32 \pm 0.10 \mathrm{bA}$ & $3.40 \pm 0.25 \mathrm{~A}$ \\
\hline & LY1 & $3.39 \pm 0.28 \mathrm{aA}$ & $3.22 \pm 0.20 a A$ & $3.38 \pm 0.16 \mathrm{bA}$ & $3.33 \pm 0.21 \mathrm{~A}$ \\
\hline & LY2 & $3.35 \pm 0.33 a A$ & $3.71 \pm 0.21 \mathrm{aA}$ & $3.70 \pm 0.13 \mathrm{bA}$ & $3.58 \pm 0.27 A$ \\
\hline \multirow{4}{*}{ Caproic, C6 } & FY & $11.30 \pm 0.26 \mathrm{cA}$ & $10.53 \pm 0.28 \mathrm{bA}$ & $8.57 \pm 0.20 \mathrm{aA}$ & $10.14 \pm 1.24 \mathrm{~A}$ \\
\hline & LY & $10.83 \pm 0.61 \mathrm{cA}$ & $9.92 \pm 0.30 b A$ & $9.04 \pm 0.93 a A$ & $9.93 \pm 0.97 A$ \\
\hline & LY1 & $10.40 \pm 0.17 c A$ & $9.85 \pm 0.32 b A$ & $9.76 \pm 0.34 \mathrm{aA}$ & $10.00 \pm 0.39 A$ \\
\hline & LY2 & $10.01 \pm 0.35 \mathrm{cA}$ & $9.57 \pm 0.27 \mathrm{bA}$ & $9.77 \pm 0.12 \mathrm{aA}$ & $9.78 \pm 0.30 \mathrm{~A}$ \\
\hline \multirow{4}{*}{ Caprylic, C8 } & FY & $9.89 \pm 0.27 c C$ & $9.16 \pm 0.05 b C$ & $8.31 \pm 0.57 \mathrm{aC}$ & $9.12 \pm 0.75 \mathrm{C}$ \\
\hline & LY & $9.62 \pm 0.24 c B$ & $8.12 \pm 0.14 b B$ & $7.79 \pm 0.18 \mathrm{aB}$ & $8.51 \pm 0.86 B$ \\
\hline & LY1 & $9.04 \pm 0.20 \mathrm{cA}$ & $7.55 \pm 0.45 b A$ & $7.35 \pm 0.11 \mathrm{aA}$ & $7.98 \pm 0.84 A$ \\
\hline & LY2 & $8.15 \pm 0.12 c A$ & $7.53 \pm 0.24 \mathrm{bA}$ & $7.66 \pm 0.14 \mathrm{aA}$ & $7.78 \pm 0.32 \mathrm{~A}$ \\
\hline \multirow{4}{*}{ Capric, C10 } & $\mathrm{FY}$ & $11.54 \pm 0.34 \mathrm{bC}$ & $10.69 \pm 0.28 \mathrm{aC}$ & $8.69 \pm 0.38 \mathrm{aC}$ & $10.31 \pm 1.30 C$ \\
\hline & LY & $10.46 \pm 0.13 \mathrm{bA}$ & $8.66 \pm 0.25 a A$ & $8.64 \pm 0.17 \mathrm{aA}$ & $9.25 \pm 0.92 \mathrm{~A}$ \\
\hline & LY1 & $9.93 \pm 0.29 \mathrm{bB}$ & $9.24 \pm 0.40 \mathrm{aB}$ & $10.16 \pm 0.14 a B$ & $9.78 \pm 0.49 B$ \\
\hline & LY2 & $9.26 \pm 0.27 \mathrm{bA}$ & $8.55 \pm 0.52 \mathrm{aA}$ & $9.53 \pm 0.23 a A$ & $9.11 \pm 0.54 \mathrm{~A}$ \\
\hline \multirow{4}{*}{ Lauric, C12 } & FY & $4.31 \pm 0.51 \mathrm{aD}$ & $4.40 \pm 0.46 a b D$ & $4.67 \pm 0.20 \mathrm{bD}$ & $4.46 \pm 0.39 D$ \\
\hline & LY & $1.52 \pm 0.17 \mathrm{aC}$ & $1.60 \pm 0.12 \mathrm{abc}$ & $1.69 \pm 0.17 b C$ & $1.60 \pm 0.15 \mathrm{C}$ \\
\hline & LY1 & $1.30 \pm 0.08 \mathrm{aB}$ & $1.27 \pm 0.19 a b B$ & $1.47 \pm 0.06 \mathrm{bB}$ & $1.35 \pm 0.14 \mathrm{~B}$ \\
\hline & LY2 & $0.94 \pm 0.03 a A$ & $0.96 \pm 0.03 a b A$ & $1.14 \pm 0.11 \mathrm{bA}$ & $1.01 \pm 0.11 \mathrm{~A}$ \\
\hline \multirow{4}{*}{ Myristik, C14 } & FY & $31.54 \pm 1.47 a D$ & $30.97 \pm 1.32 \mathrm{aD}$ & $31.76 \pm 0.71 \mathrm{aD}$ & $31.42 \pm 1.11 \mathrm{D}$ \\
\hline & LY & $23.72 \pm 0.40 \mathrm{aC}$ & $28.30 \pm 1.42 \mathrm{aC}$ & $27.85 \pm 0.39 a C$ & $26.62 \pm 2.32 \mathrm{C}$ \\
\hline & LY1 & $22.58 \pm 0.34 a B$ & $18.69 \pm 0.30 a B$ & $18.83 \pm 0.06 a B$ & $20.03 \pm 1.93 B$ \\
\hline & LY2 & $18.61 \pm 0.19 a A$ & $17.58 \pm 0.29 \mathrm{aA}$ & $18.07 \pm 0.15 \mathrm{aA}$ & $18.09 \pm 0.48 \mathrm{~A}$ \\
\hline \multirow{4}{*}{ Palmitic, C16 } & FY & $91.74 \pm 5.99 a D$ & $96.38 \pm 3.55 b D$ & $97.55 \pm 2.03 \mathrm{bD}$ & $95.22 \pm 4.50 \mathrm{D}$ \\
\hline & LY & $68.30 \pm 1.48 \mathrm{aC}$ & $71.70 \pm 0.44 \mathrm{bc}$ & $71.91 \pm 0.41 b C$ & $70.64 \pm 1.93 C$ \\
\hline & LY1 & $54.03 \pm 2.80 \mathrm{aB}$ & $56.92 \pm 3.10 \mathrm{bB}$ & $59.08 \pm 1.38 \mathrm{bB}$ & $56.68 \pm 3.11 \mathrm{~B}$ \\
\hline & LY2 & $44.26 \pm 0.86 a A$ & $50.07 \pm 1.71 \mathrm{bA}$ & $51.92 \pm 0.62 \mathrm{bA}$ & $48.75 \pm 3.60 A$ \\
\hline \multirow{4}{*}{ Stearic, C18 } & FY & $28.36 \pm 0.21 c C$ & $27.06 \pm 0.09 \mathrm{bc}$ & $25.53 \pm 0.42 \mathrm{aC}$ & $26.98 \pm 1.25 C$ \\
\hline & LY & $5.34 \pm 0.44 c B$ & $5.31 \pm 0.26 b B$ & $5.15 \pm 0.14 a B$ & $5.27 \pm 0.28 \mathrm{~B}$ \\
\hline & LY1 & $4.25 \pm 0.19 c A$ & $4.26 \pm 0.06 \mathrm{bA}$ & $4.19 \pm 0.07 \mathrm{aA}$ & $4.24 \pm 0.11 \mathrm{~A}$ \\
\hline & LY2 & $4.12 \pm 0.09 c A$ & $4.18 \pm 0.07 b A$ & $4.12 \pm 0.03 a A$ & $4.14 \pm 0.06 \mathrm{~A}$ \\
\hline \multirow{4}{*}{ C18:1 } & FY & $29.15 \pm 0.98 a D$ & $30.89 \pm 0.29 b D$ & $31.89 \pm 0.05 c D$ & $30.64 \pm 1.30 D$ \\
\hline & LY & $13.10 \pm 0.13 a C$ & $13.83 \pm 0.10 \mathrm{bC}$ & $14.20 \pm 0.05 c C$ & $13.71 \pm 0.49 \mathrm{C}$ \\
\hline & LY1 & $12.82 \pm 0.28 \mathrm{aB}$ & $13.04 \pm 0.28 \mathrm{bB}$ & $13.37 \pm 0.31 c B$ & $13.08 \pm 0.35 B$ \\
\hline & LY2 & $11.78 \pm 0.21 \mathrm{aA}$ & $12.44 \pm 0.09 \mathrm{bA}$ & $12.76 \pm 0.08 \mathrm{cA}$ & $12.33 \pm 0.45 \mathrm{~A}$ \\
\hline
\end{tabular}

* FY: Fatty yoghurt (\% 3 fat+\% 0 WPI); LY: Low fat yoghurt ( $\leq \% 0.5$ fat+\% 0 WPI); LY1: $1 \%$ WPI added yoghurt ( $\leq \% 0.5$ fat+\% $1 \mathrm{WPI}) ; \mathrm{LY} 2: 2 \% \mathrm{WPI}$ added yoghurt ( $\leq \% 0.5$ fat $+\% 2 \mathrm{WPI})$.

${ }^{a-c}$ The same column with different superscripts among yoghurt samples significantly differ $(P<0.05)$.

${ }^{A-D}$ The same row with different superscripts among yoghurt samples significantly differ $(P<0.05)$

\section{REFERENCES}

Anonymous (1989) Yoğurt Standardı TSE 1330 Necatibey Cad. No. 112.

Anonymous (1994) Çiğ Süt Standardı TSE 1018 Necatibey Cad. No. 112.

Anonymous (2016) Dairy Sector Statistics in Turkey and in the World, Turkish National Milk Council Report.

AOAC (2000) Official Methods of Analysis of AOAC International Assoc. Off. Anal. Chem. Int. Method Ce. Association of Official Analysis Chemists International: 2-66.

AOAC (2010) Association of Official Analysis Chemists International Official Methods of Analysis of AOAC International 962.09. 6th ed.
Beshkova D, Simova E, Frengova G, Simov Z (1998) Production of Flavour Compounds by Yogurt Starter Cultures. Journal of Industrial Microbiology and Biotechnology 20 (3-4): 180-86.

Damin M R, Alcântara M R, Nunes A P, Oliveira M N (2009) Effects of Milk Supplementation with Skim Milk Powder, Whey Protein Concentrate and Sodium Caseinate on Acidification Kinetics, Rheological Properties and Structure of Nonfat Stirred Yogurt. LWT - Food Science and Technology 42 (10): 1744-50.

Guggisberg D (2009) Rheological, Microstructural and Sensory Characterization of Low-Fat and Whole Milk Set Yoghurt as Influenced by Inulin Addition. International Dairy Journal 19 (2): 107-15. 
Guggisberg D, Eberhard P, Albrecht B (2007) Rheological Characterization of Set Yoghurt Produced with Additives of Native Whey Proteins. International Dairy Journal 17 (11): 1353-59.

Guggisberg D, Piccinali P, Schreier K (2011) Effects of Sugar Substitution with Stevia, Actilight ${ }^{\mathrm{TM}}$ and Stevia Combinations or Palatinose ${ }^{\mathrm{TM}}$ on Rheological and Sensory Characteristics of Low-Fat and Whole Milk Set Yoghurt. International Dairy Journal 21 (9): 63644.

Güler Z (2007) Changes in Salted Yoghurt during Storage. International Journal of Food Science and Technology 42 (2): 235-45.

Güler Z, Gürsoy-Balci A C (2011) Evaluation of Volatile Compounds and Free Fatty Acids in Set Types Yogurts Made of Ewes', Goats' Milk and Their Mixture Using Two Different Commercial Starter Cultures during Refrigerated Storage. Food Chemistry 127 (3): 106571.

Güler Z, Park YW (2011) Characteristics of Physico-Chemical Properties, Volatile Compounds and Free Fatty Acid Profiles of Commercial Set-Type Turkish Yoghurts. Open Journal of Animal Sciences 01 (01): 1-8.

Kesenkas H, Dinkçi N, Seçkin K, Kınık Ö, Gönç S, Ergönül P G, Kavas G (2011) Physicochemical, microbiological and sensory characteristics of soymilk kefir. African Journal of Microbiology Research 5 (22), 3737-3746

Hull, M E (1947) Studies on Milk Proteins. II. Colorimetric Determination of the Partial Hydrolysis of the Proteins in Milk. Journal of Dairy Science 30 (11): 881-84.

Ibrahim O, Glibowski P, Nour M, El-Hofi M, El-Tanboly E, And-Rabou N (2017) Effect of rosemary transglutaminase on yoghurt fortified with whey protein isolate. Polish Journal of Food and Nutrition Sciences 67 (4), 265-274.

Isleten M, Karagul-Yuceer Y (2006) Effects of Dried Dairy Ingredients on Physical and Sensory Properties of Nonfat Yogurt. Journal of Dairy Science 89 (8): 286572.

Kaminarides S, Paraskeri S, Theophiles M (2007) Comparison of the Characteristics of Set Type Yoghurt Made from Ovine Milk of Different Fat Content. International Journal of Food Science and Technology 42 (9): 1019-28.

Lasik A D, Pikul J, Majcher M, Lasik-Kurdys M, Konieczny $\mathrm{P}$ (2016) Characteristics of fermented ewe's milk product with an increased ratio of natural whey proteins to caseins. Small Ruminant Research 144, 283-289.

Matumoto-Pintro P T, Rabiey L, Robitaille G, Britten M (2011) Use of Modified Whey Protein in Yoghurt
Formulations. International Dairy Journal 21 (1): 2126.

Onsekizoglu Bagci P, Gunasekaran S (2016) IronEncapsulated Cold-Set Whey Protein Isolate Gel Powder - Part 2: Effect of Iron Fortification on Sensory and Storage Qualities of Yoghurt. International Journal of Dairy Technology 69 (4): 601-8.

Patocka G, Cervenkova R, Narine S, Jelen P (2006) Rheological Behaviour of Dairy Products as Affected by Soluble Whey Protein Isolate. International Dairy Journal 16 (5): 399-405.

Rao D R, Reddy J C (1984) Effects of Lactic Fermentation of Milk on Milk Lipids. Journal of Food Science 49 (3): 748-50.

Reguta A (2007) Free Fatty Acid Profiles of Fermented Beverages Made from Ewe's Milk. Lait 87 (1): 71-77.

Şenel E, Atamer M, Gürsoy A, Öztekin F Ş (2011) Changes in Some Properties of Strained (Süzme) Goat's Yoghurt during Storage. Small Ruminant Research 99 (2-3): 171-77.

Shi J, Li D, Zhao X H (2017) Atributos Cualitativos Del Yogur Desnatado Preparado Con Aislado Proteínico de Lactosuero Con Reticulación Encimática o Polimerizado Térmico. CYTA - Journal of Food 15 (1): 34-40.

Sumarmono J, Sulistyowati M, Soenarto ? (2015) Fatty Acids Profiles of Fresh Milk, Yogurt and Concentrated Yogurt from Peranakan Etawah Goat Milk. Procedia Food Science 3: 216-22.

Torres I C, Amigo J M, Knudsen J C, Tolkach A, Mikkelsen B $Q$, Ispen R (2018) Rheology and microstructure of low-fat yoghurt produced with whey protein microparticles as fat replacer. International Dairy Journal 81: 62-71.

Walsh-O'grady CD, O-Kennedy BT, Fitzgerald RJ,Lane CN (2001) A Rheological Study of Acid-Set Simulated Yogurt Milk Gels Prepared from Heat-or PressureTreated Milk Proteins. Lait 81 (5): 637-50.

Wang C, Gao F, Zhang T, Wang Y, Guo M (2015) Physiochemical, textural, sensory properties and probiotic survivability of Chinese Laosuan Nai (protein fortified set yoghurt) using polymerized whey protein as a co-thickening agent. International Journal of Dairy Technology 68 (2), 261-268.

Yıldız-Akgül F (2018) Enhancement of Torba Yoghurt with Whey Protein Isolates. International Journal of Dairy Technology 71 (4): 898-905.

Zhang T, McCarthy J, Wang C, LiuY, Guo M (2015) Physiochemical Properties, Microstructure, and Probiotic Survivability of Nonfat Goats' Milk Yogurt Using Heat-Treated Whey Protein Concentrate as Fat Replacer. Journal of Food Science 80 (4): 788-794. 